\title{
Metabolomics and Bladder Cancer: Current State and Future Perspectives
}

\section{Metabolómica no Carcinoma da Bexiga: Estado Atual e Perspetivas Futuras}

\author{
Hugo Antunes ${ }^{1 *}$, Edgar Tavares-da-Silva1,2,3, Inês Marques²,3, João Carvalho', Ana Margarida Abrantes ${ }^{2,3}$, Marco Alves4, \\ Maria Filomena Botelho ${ }^{2,3}$, Arnaldo Figueiredo ${ }^{1,2}$
}

\section{Abstract}

Introduction: Bladder cancer is the ninth common tumor worldwide and the most common malignant carcinoma of urinary system with an increasing incidence. Despite the high frequency and mortality associated with this carcinoma, little has evolved recently regarding the diagnosis and management of this type of tumor. In fact, cystoscopy and cytology are still standards for bladder cancer detection. The development of less invasive and more reliable diagnostic techniques of bladder cancer than cystoscopy and cytology is critical. In this sense, metabolomics has recently emerged as a promising technique for the diagnosis and orientation of oncological diseases.

Evidence Acquisition: We searched PubMed, Medline and Web of Science for studies about metabolomics and bladder cancer published before October 2017. We performed a review of the literature, trying to clarify what is already known about the application of metabolomics in bladder cancer and what are the future prospects.

Evidence Synthesis: The spectral acquisition is made using predominantly two analytic platforms: nuclear magnetic resonance and mass spectrometry. Regarding to bladder cancer, several metabolites were associated with the presence of bladder cancer, leading to the creation of a metabolomic profile capable of distinguishing between bladder cancer patients and control. Besides the diagnosis, the metabolomic has also been studied to stratify bladder cancer according to its aggressiveness. In this sense there are studies that used metabolomic analysis to distinguish between low-grade and high-grade bladder cancer. One investigation showed that the levels of carnitine were higher in muscle-invasive bladder cancer than in nonmuscle-invasive bladder cancer, which suggests that they may be correlated with bladder cancer aggressiveness.

Conclusion: Biomarkers detected by metabolomics give an insight into cancer biology and tapped properly this can lead to new strategies for bladder cancer diagnosis and new drugs discovery.

'Serviço de Urologia e Transplantação Renal, Centro Hospitalar e Universitário de Coimbra, Coimbra, Portugal

${ }^{2}$ Centro de Investigação em Meio Ambiente, Genética e Oncobiologia (CIMAGO), Coimbra, Portugal

${ }^{3}$ Instituto Biomédico de Investigação da Luz e da Imagem (IBILI), Coimbra, Portugal

${ }^{4}$ Instituto de Ciências Biomédicas Abel Salazar, Universidade do Porto, Porto, Portugal

\section{Resumo}

Introdução: O carcinoma da bexiga é o nono tumor mais comum em todo o mundo e o tumor mais comum do sistema urinário com incidência crescente. Apesar da alta frequência e mortalidade associada a este tumor, pouco evoluiu recentemente quanto ao diagnóstico e tratamento desta patologia. De facto, a cistoscopia e a citologia urinária ainda são os métodos preconizados para a detecção do carcinoma da bexiga. O desenvolvimento de técnicas diagnósticas menos invasivas e mais confiáveis é fundamental. Nesse sentido, a metabolómica surgiu recentemente como uma técnica promissora para o diagnóstico e orientação de doenças oncológicas.

Aquisição de Evidências: Fizemos uma pesquisa exaustiva dos estudos sobre metabolómica e carcinoma da bexiga publicados antes de Outubro de 2017, recorrendo à base bibliográfica da PubMed, Medline e Web of Science. Realizamos uma revisão da literatura, tentando esclarecer o que já é conhecido sobre a aplicação da metabolómica no carcinoma da bexiga e quais as perspectivas futuras.

Síntese de Evidências: A aquisição espectral é feita usando predominantemente duas plataformas analíticas: ressonância magnética e espectrometria de massa. No que diz respeito ao carcinoma da bexiga, vários metabolitos foram associados à presença de tumor, levando à criação de um perfil metabolómico capaz de identificar os pacientes com carcinoma da bexiga. Além do diagnóstico, a metabolómica também foi estudada para estratificar os casos de carcinoma da bexiga de acordo com sua agressividade. Neste sentido, existem estudos que utilizaram a análise metabolómica para distinguir entre tumores vesicais de baixo e alto grau. Uma investigação mostrou que os níveis de carnitina foram maiores nos doentes com carcinoma da bexiga músculo-invasivo do que naqueles com tumores não invasivos, o que sugere que estes achados podem estar correlacionados com a agressividade tumoral. Conclusão: Os biomarcadores detectados pela metabolómica fornecem uma visão da biologia tumoral e usados de forma adequada poderão levar ao desenvolvimento de novas estratégias para o diagnóstico e tratamento do carcinoma da bexiga. 
Keywords: Biomarkers, Tumor; Metabolome; Metabolomics; Urinary Bladder Neoplasms.
Palavras-chave: Biomarcadores Tumorais; Metaboloma; Metabolómica; Neoplasias da Bexiga Urinária.

\section{Introduction}

Bladder cancer (BC) is the ninth common tumor worldwide 1,2 and the most common malignant carcinoma of urinary system with an increasing incidence. ${ }^{3}$ Most of BC cases (about $75 \%$ ) are non-invasive low-grade and high-grade urothelial papillomas with high recurrence rates after surgical resection. The remaining cases are muscle-invasive $\mathrm{BC}$ that present an aggressive behavior with high rate of metastization. ${ }^{4}$ Whereas low-grade papillary urothelial carcinoma progresses only in a minority of patients, those with high-grade nonmuscle-invasive bladder cancer (NMIBC) have a markedly increased risk of progression. ${ }^{5}$ Muscle-invasive bladder cancer (MIBC) is an aggressive disease associated with high morbidity and mortality. Primary treatment in these cases includes radical cystectomy and bilateral regional lymph node dissection with or without neoadjuvant chemotherapy. ${ }^{6}$ Despite the high frequency and mortality associated with this carcinoma, little has evolved recently regarding the diagnosis of this type of tumor. In fact, cystoscopy and cytology are still standards for BC detection. Cystoscopy is an invasive and costly procedure. ${ }^{7}$ Cytology is a noninvasive method used in the diagnosis of $\mathrm{BC}$ in conjunction with cystoscopy. Although cytology has high specificity, its sensitivity is reduced, particularly in low-grade tumors. ${ }^{8}$ Furthermore, the follow-up of patients with NMIBC is also done with regular cystoscopy and urinary cytology, which has increased costs for hospitals and patients. Thus, the development of less invasive and more reliable diagnostic techniques of BC than cystoscopy and cytology is critical. Several candidate protein markers for $\mathrm{BC}$ have been identified from urine and BC cells, however the sensitivity and specificity of these markers are not superior to existing detection methods. ${ }^{9-11}$ Thus, the development of new markers for diagnosis and follow-up of patients with BC is in need.

Metabolomics has recently emerged as a promising technique for the diagnosis and orientation of oncological diseases, given its noninvasive sampling characteristics and robust analytical feasibility. ${ }^{12}$ Metabolomics can be defined as the nontargeted analysis of all of the small molecule metabolites produced by the body. These compounds are generally accepted to be $\leq 1500 \mathrm{Da}$ and to include peptides, oligonucleotides, sugars, nucleosides, organic acids, ketones, aldehydes, amines, amino acids, lipids, steroids, and alkaloids, and in some cases drugs or xenobiotic. ${ }^{13}$ At the basis of the development of metabolomics applied to the study of cancer is the principle of that most of the metabolic processes in the body, such as those involving energetics and amino acid catabolism, are common to all living cells. In addition, cancer cells show likely a wide range of changes in metabolic pathways such as glycolysis, amino acid metabolism, and fatty-acid oxidation. ${ }^{13}$

The entire qualitative collection of metabolites in a biological sample is called "metabolome", which is very dynamic. ${ }^{14} \mathrm{Me}-$ tabolites represent the end products of cellular biochemical and physiological processes. Thus, the study of metabolome in combination with transcriptomics and proteomics will help to better understand the pathogenesis of the disease and consequently will also help to find more appropriate treatment approaches. ${ }^{14}$ So, exploring cancer metabolome seems to be an effective way to understand the phenotypic changes associated with cancer. ${ }^{15}$

The interest in metabolomics has increased exponentially in last years, and there are already several studies on novel cancer biomarkers discovered by metabolomics in various types of cancers. A study focused on lung cancer, investigating the metabolic profile of patients with benign and malignant nodules, was able to identify 14 metabolites associated with malignant pulmonary nodules. ${ }^{16}$ Another study used the serum metabolic profile to categorize breast cancer patients as responders or non-responders to chemotherapy. ${ }^{17}$ They found the concentration of four metabolites was significantly different in patients and controls when comparing response to chemotherapy. The metabolites correctly identified $80 \%$ of the patients whose tumors did not show complete response to chemotherapy.

Several studies of metabolomics have also been developed in the area of urological tumors. A recent study found 8 metabolites whose concentrations exhibited statistically significant differences when comparing the urinary metabolomic profiles of prostate cancer ( $\mathrm{PCa}$ ) and individuals diagnosed with benign prostatic hyperplasia (BPH). They found that urine from $\mathrm{PCa}$ patients, compared with individuals diagnosed with $\mathrm{BPH}$, was characterized by increased concentrations of branchedchain amino acids (BCAA), glutamate and pseudouridine, and decreased concentrations of glycine, dimethylglicine, fumarate, 4-imidazole-acetate and one unknown metabolite. ${ }^{18}$ Many studies have also been developed in BC to find metabolites that can improve the management of patients with $B C .^{19,20}$ Thus, the objective of this study is to review the application of metabolomics in BC, seeking to assess the current state and future prospects.

\section{Evidence Acquisition}

We searched PubMed, Medline and Web of Science for studies about metabolomics and BC published before October 2017. We used the following search strings: metabolic profil- 
Table 1: Characteristics and major findings of metabolomic studies in bladder cancer

\begin{tabular}{|c|c|c|c|c|c|c|}
\hline Study & Year & Method & $\begin{array}{l}\text { Patients/ } \\
\text { Controls }\end{array}$ & $\begin{array}{l}\text { Metabolites } \\
\text { identified }\end{array}$ & Key metabolites & Major findings \\
\hline Kim et $a^{38}$ & 2010 & GC-MS & $11 / 8$ & 21 & $\begin{array}{l}\text { B-aminoisobutyric acid, pyroglutamic } \\
\text { acid, tyrosine, and glycine }\end{array}$ & $\begin{array}{l}\text { The patient star pattern of } \\
21 \text { amino acids was badly } \\
\text { distorted compared with the } \\
\text { controls }\end{array}$ \\
\hline Srivastava et $a^{28}$ & 2010 & H-NMR & $33 / 37$ & 11 & Taurine, hippurate and citrate & $\begin{array}{l}\text { Significant decrease in con- } \\
\text { centrations of hippurate and } \\
\text { citrate and increase in that of } \\
\text { taurine were observed in bla- } \\
\text { dder cancer urine samples }\end{array}$ \\
\hline Pasikanti et $a^{\beta 9}$ & 2010 & GC-MS & $24 / 51$ & 15 & $\begin{array}{l}\text { Senecioic acid, 2-butenedioic acid, } \\
\text { ribonic acid, 2,5-furandicarboxylic } \\
\text { acid, melibiose, sumiki's acid, uridine, } \\
\text { 2-propenoic acid, glycerol, gluconic } \\
\text { acid, valerate, fructose, Lvaline, citric } \\
\text { acid, ribitol }\end{array}$ & $\begin{array}{l}\text { AUC 0.90; Sensitivity } 92 \% \text {; } \\
\text { Specificity } 80 \%\end{array}$ \\
\hline Huang et $a^{40}$ & 2011 & LC-MS & $27 / 32$ & 14 & $\begin{array}{l}\text { Component I; carnitine C9:1 and } \\
\text { hippuric acid }\end{array}$ & $\begin{array}{l}\text { AUC 0.96; Sensitivity } 92.6 \% \\
\text { Specificity } 96.9 \%\end{array}$ \\
\hline Pasikanti et a $/^{19}$ & 2013 & GC-MS & $38 / 61$ & 46 & $\begin{array}{l}\text { Tryptophan, anthranilic acid, quinolinic } \\
\text { acid, pcresol, vanillylmandelic acid, } \\
\text { 3,4-dihydroxy-phenylpyruvate, uridine, } \\
\text { pseudouridine, 2-aminoisobutyric acid, } \\
\text { citric acid }\end{array}$ & $\begin{array}{l}\text { AUC 0.88; Sensitivity } \\
71 \% ; \text { Specificity } 100 \%\end{array}$ \\
\hline Alberice et $a^{\beta 4}$ & 2013 & LC-MS & $\mathrm{N} / \mathrm{A}$ & 27 & $\begin{array}{l}\text { Betaine, cystrine, histidine, tyrosine, } \\
\text { phenylalanine, tryptophan, carnosine, } \\
\text { decanoylcarnitine, uric acid; trime- } \\
\text { thyllysine, } \mathrm{N} \text {-acetyl tryptophan, dopa- } \\
\text { quinone, leucine and hypoxanthine }\end{array}$ & $\begin{array}{l}27 \text { metabolite features were } \\
\text { significantly different for } \\
\text { distinguishing tumor stage } \\
\text { and recurrence }\end{array}$ \\
\hline Jin et $a^{29}$ & 2014 & LC-MS & $138 / 121$ & 12 & $\begin{array}{l}\text { Succinate, pyruvate, oxoglutarate, } \\
\text { carnitine, phosphoenolpyruvate, } \\
\text { trimethyllysine, melatonin,isovaleryl- } \\
\text {-carnitine, glutarylcarni-tine, octenoyl- } \\
\text { carnitine, decanoylcarnitine, } \\
\text { acetylCoA }\end{array}$ & $\begin{array}{l}12 \text { differential metabolites } \\
\text { between the bladder cancer } \\
\text { and control groups were } \\
\text { found. Sensitivity } 91.3 \% \text { and } \\
\text { specificity } 92.5 \%\end{array}$ \\
\hline Wittmann et $a^{\beta 3}$ & 2014 & $\begin{array}{l}\text { LC-MS / } \\
\text { GC-MS }\end{array}$ & $\begin{array}{l}\text { Cohort } \\
\text { 1:66:266 } \\
\text { Cohort } \\
2: 29: 79\end{array}$ & 587 & $\begin{array}{l}\text { Lactate, palmitoyl sphingomyelin, ade- } \\
\text { nosine, succinate, phosphocholine, } \\
\text { guanidinoacetate, arachidonate,sper- } \\
\text { mine, cytosine, spermidine }\end{array}$ & $\begin{array}{l}25 \text { candidate biomarkers } \\
\text { were tested, of which } 4 \\
\text { metabolites provided the } \\
\text { strongest predictive power }\end{array}$ \\
\hline
\end{tabular}

ing, bladder cancer, nuclear magnetic resonance spectrometry and mass spectrometry. We performed a review of the literature, trying to clarify what is already known about the application of metabolomics in $\mathrm{BC}$ and what are the future prospects.

\section{Evidence Synthesis}

Methods of metabolite evaluation: A metabolomics approach includes steps of sample collection, sample preparation, spectral acquisition and data analysis. ${ }^{21}$ With regard to sample collection, several biological tissues may be used for the evaluation of metabolites. Examples of such biological specimens are urine, feces, tissues, blood, saliva sputum, seminal fluid and cerebrospinal fluid. ${ }^{21}$ Sample preparation is essential to remove the chemicals of interest from a complex matrix. This preparation increases sensitivity, specificity and robustness of the technique. This sample preparation may be as simple as filtration and protein removal or as complex as multistep orthogonal workflows. ${ }^{21}$

The spectral acquisition is made using predominantly two analytic platforms: nuclear magnetic resonance (NMR) and mass spectrometry (MS). ${ }^{15,21}$ There are other methods that can be used in this analysis, however the characteristics of NMR and MS have made these two platforms the most commonly used methods for metabolomics studies. ${ }^{21}$ Both techniques 
allow extensive and rapid analysis of small molecule metabolites. ${ }^{22}$ MS can be coupled with a separation technique such as gas chromatography (GC-MS), liquid chromatography (LC-MS) or capillary electrophoresis (CE-MS). ${ }^{23}$

NMR is considered the gold-standard method for analyze identification and gives a directly quantitative measurement relating amount of analyte to signal. ${ }^{24}$ This technique has undergone rapid improvements with the development of stronger magnets resulting in increased field strength, hyperpolarization techniques leading to increased signal to noise and advanced pulse techniques resulting in narrower resonances. With the use of ultra-shielded magnets, it is possible to combine flow-injection NMR and MS to a total analysis system with minimized space requirements and controlled by single software. ${ }^{21}$

On the other hand, MS plays a pivotal role in metabolomic evaluation due to its high sensitivity and widespread availability. ${ }^{25}$ The ionization mode selected has a significant effect on the metabolic profile that is obtained. ${ }^{25}$ In MS analysis, molecules are ionized and introduced into mass spectrometer, then separated and analyzed resulting in the determination of the mass-to-charge ratio $(\mathrm{m} / \mathrm{z})$. A single analyte may give rise to multiple $\mathrm{m} / \mathrm{z}$ values due to multiple charge states and adduct formation resulting in collinear values. It should be noted that MS is not inherently a quantitative tool. Metabolite identification has been significantly improved with accurate databases and tandem MS fragmentation information. Although, this still remains a very labor-intensive endeavor, particularly for lipid-derived metabolites. ${ }^{21}$ GC-MS and LC-MS are perhaps the most commonly used platforms in metabolomics of cancer samples. GC-MS is used to the analysis of low molecular weight metabolites. ${ }^{26}$ LC-MS is applied to the analysis of non-volatile chemicals, therefore it is complementary to GCMS ${ }^{26}$ Lastly, CE-MS is useful to the separation and detection of polar or ionic compounds in low sample volumes. ${ }^{23}$

Thus, NMR instruments coupled with LC-MS represent the ultimate metabolomics tool by providing overlapping and no overlapping information. NMR is the main instrument in the quantitative analysis of highly abundant small molecules and is able to give an overview of changes in biological sample without prior knowledge. MS, on the other hand, is the dominant technique for the analysis of compounds at low abundance. ${ }^{21}$ In conclusion, different analytical platforms are suited to different types of samples. Besides that, it is crucial to choosing the right analytical platform for the application, choosing the correct way to prepare a sample based on its type and the instrument to be employed for the experiment. ${ }^{23}$

Current trends in BC management: Several studies have been developed recently in the search to find biomarkers that allow an early diagnosis of $\mathrm{BC}$, as well as the identification of metabolites capable of predicting the response to chemo- therapy or relapse risk. The most important studies and their major findings are listed in Table 1. Regarding the diagnosis several studies have compared the metabolic profile of urine samples in patients with $\mathrm{BC}$ and control patients. Issaq et a ${ }^{27}$ using a LC-MS method were able to correctly identify 48 of 48 controls and 41 of 41 bladder cancer patients. In another study, Srivastava et al using ${ }^{1} \mathrm{H}$ NMR spectroscopy found significant variations in urine concentrations of hippurate, citrate and taurine in $\mathrm{BC}$ patients compared with controls. ${ }^{28} \mathrm{Jin}$ et a ${ }^{29}$ defend in their work that patients with $\mathrm{BC}$ could be clearly distinguished from patients from the control groups on the basis of their metabolomic profiles. This group goes further and argues that patients with MIBC could also be distinguished from patients with NMIBC through the evaluation of its metabolomic profile. In this same study, it was evaluated the performance of the used multivariate model in the diagnosis of BC. The orthogonal projections to latent structure-discriminant analysis (OPLS-DA) model with one predictive and two orthogonal components separated the cancer groups (NMIBC and MIBC) reasonably well $(\mathrm{R} 2=0.875$ and $\mathrm{Q} 2=0.355) .{ }^{29}$ Their prediction model showed a sensitivity of $91.3 \%$ and a specificity of $92.5 \%$. Shen and colleagues ${ }^{30}$ identified three BC upregulated metabolites: nicotinuric acid, trehalose, AspAspGlyTrp and three post-surgery BC downregulated metabolites: inosinic acid, ureidosuccinic acid and GlyCysAlaLys. They also found that analysis of six post-surgery BC urine samples showed that these BC-metabolomic features reverted to normal state after tumor resection, suggesting that they reflect metabolomic features associated with BC. Several other studies have been developed with the aim of finding a metabolic profile that allows the identification of $\mathrm{BC}$ using different sample types: urine, plasma or serum and bladder tissue. ${ }^{19,20,31-33}$

Although most studies have focused on the diagnosis of BC, some studies have also shown the usefulness of metabolomics in the classification of tumors in function of their aggressiveness. Jin and colleagues, in the same work referred to above ${ }^{29}$ showed that the levels of carnitine were higher in MIBC than NMIBC, which suggests that they may be correlated with $\mathrm{BC}$ aggressiveness.

In another study, investigators used both LC-MS and CEMS of urine and identified that a total of 27 metabolites were significantly different between patients who developed tumor recurrence and those who did not. ${ }^{34} \mathrm{~A}$ recent study ${ }^{35}$ shows distinct profiles of nonmuscle-invasive and muscle-invasive bladder cancer. They found that MIBC appears to preferentially enhance cyclooxygenase and lipoxygenase signaling, increase heme catabolism and alter nicotinamide adenine dinucleotide synthesis with a possible influence from associated inflammatory cells. Bansal et al could differentiate LG from $H G$ with $97 \%$ sensitivity and $99 \%$ specificity, using $1 \mathrm{H}$ NMR-derived serum data. ${ }^{36}$ The changes in some metabolites 
such as lactate, tyrosine, glycine, carnitine and others were consistent with BC aggressiveness and stage of metastasis. These results suggest that different stages/grades of $\mathrm{BC}$ might generate different metabolic profiles. ${ }^{37}$

Future perspectives: Despite the recent findings and growing interest in the study of metabolomics, its application in clinical practice requires further investigation. At this time the application of metabolomics in cancer research still presents some limitations. In fact, the studies performed so far have been carried out with few patients and with small validation cohorts that makes it difficult to apply the metabolomics in clinical practice. Additionally, there is some inconsistency between biomarkers identified among studies, even when the same specimens were analyzed. ${ }^{37}$ Thus, in the future it will be necessary to find ways to overcome these limitations in order to apply the metabolomics in clinical practice. However, metabolomics presents as a tool with enormous future potential. Several markers have been developed at DNA, RNA and protein levels to BC diagnosis, however its sensitivity, specificity and accessibility were not yet acceptable in order to alter the BC diagnosis paradigm. ${ }^{41}$ Thus, future research should not only look for ways to standardize the diagnosis but also find ways to distinguish LG and HG tumors. Another area to be explored in the future is the ability of the metabolomics to help identify the main metabolic pathways involved in tumor progression and thus allows the discovery of new therapeutic targets. In regard to this subject, there are already some studies using metabolomics to try to predict the response to chemotherapy in other types of tumors. Fujimura et $a^{142}$ used a metabolic approach to analyze gemcitabine resistance verified in some pancreatic cancer patients. This study identified metabolites related to several metabolic pathways such as amino acid, nucleotide, energy, cofactor, and vitamin pathways. Decreases in glutamine and proline levels as well as increases in aspartate, hydroxyproline, creatine, and creatinine levels were observed in chemoresistant cells. Metabolites identified in this work may serve as biomarkers capable of predicting sensitivity to gemcitabine, which has so far been part of the standard therapy for metastatic BC. Another study, focused on gastric carcinoma, described a metabolic approach for chemosensitivity prediction in a human xenograft model of gastric cancer treated with cisplatin and 5-fluorouracil. ${ }^{43}$ With the use of MS techniques this study proposed 18 chemosensitivity metabolites for gastric cancer. Therefore, it seems that the metabolomics, perhaps in combination with proteomics and genomics, will play a crucial role in future discoveries of new treatments for cancer, including BC.

\section{Conclusion}

Our review has several limitations. The possibility of publication bias exists, and eligible studies may have been omitted despite a careful literature search. In some of the studies presented, tumor stages and grades were not elaborated. Thus, evaluating the diagnostic effects of these potential biomarkers was difficult.

The use of metabolomics in BC management still needs improvement, but it remains a promising option. Biomarkers detected by metabolomics give an insight into cancer biology and tapped properly this can lead to new strategies for $\mathrm{BC}$ diagnosis and new drugs discovery. Further studies are needed to understand in a concrete way the extent to which metabolomics can be integrated into the clinical practice of patients with $\mathrm{BC}$.

\section{Ethical Disclosures}

Conflicts of interest: The authors report no conflict of interest. Funding sources: No subsidies or grants contributed to this work.

Financing Support: This work has not received any contribution, grant or scholarship.

\section{Responsabilidades Éticas}

Conflitos de Interesse: Os autores declaram a inexistência de conflitos de interesse na realização do presente trabalho.

Fontes de Financiamento: Não existiram fontes externas de financiamento para a realização deste artigo.

\section{${ }^{*}$ Corresponding Author $/{ }^{\star}$ Autor Correspondente \\ Hugo Manuel Pontes Antunes \\ Address: Rua Padre Sebastião, $n^{\circ} 12$ \\ $2^{\circ} \mathrm{C}, 3040-376$ Coimbra, Portugal \\ E-mail: hugoantunes4@gmail.com}

Recebido/Received: 2017-11-23

Aceite/Accepted: 2018-04-22

\section{REFERENCES}

1. Torre LA, Bray F, Siegel RL, Ferlay J, Lortet-tieulent J, Jemal A. Global Cancer Statistics, 2012. CA Cancer J Clin. 2015:65:87-108.

2. Ferlay J, Soerjomataram I, Dikshit R, Eser S, Mathers C, Rebelo M, et al. Cancer incidence and mortality worldwide: Sources, methods and major patterns in GLOBOCAN 2012. Int J Cancer. 2015;136:E359-E386.

3. Siegel RL, Miller KD, Jemal A. Cancer statistics, 2016. CA Cancer J Clin 2016;66:7-30

4. Khandelwal P, Abraham SN, Apodaca G. Cell biology and physiology of the uroepithelium. Am J Physiol Renal Physiol. 2009;297:F1477-501.

5. Kamat AM, Mathew P. Bladder cancer: imperatives for personalized medicine. Oncology. 2011;25:951-8, 960.

6. Lobo N, Mount C, Omar K, Nair R, Thurairaja R, Khan MS. Landmarks in the treatment of muscle-invasive bladder cancer. Nat Rev Urol. 2017:11:476-80

7. van der Poel H, Debruyne F. Can biological markers replace cystoscopy? An update. Curr Opin Urol. 2001:11:503-9.

8. Konety BR. Molecular markers in bladder cancer: a critical appraisal. Uro Oncol. 2006;24:326-37

9. Lokeshwar VB, Habuchi T, Grossman HB, Murphy WM, Hautmann SH, Hemstreet GP 3rd, et al. Bladder tumor markers beyond cytology: International Consensus Panel on bladder tumor markers. Urology. 2005;66(Suppl.1):35-63.

10. Bolenz C, Lotan Y. Molecular biomarkers for urothelial carcinoma of the bladder: challenges in clinical use. Nat Clin Pract Urol. 2008;5:676-85.

11. Kim WJ, Bae SC. Molecular biomarkers in urothelial bladder cancer. Cancer Sci. 2008;99:646-52.

12. Burton $\mathrm{C}, \mathrm{Ma} \mathrm{Y}$. Current trends in cancer biomarker discovery using urinary metabolomics: achievements and new challenges. Curr Med Chem. 2017 (in press). doi: 10.2174/0929867324666170914102236

13. Aboud $\mathrm{OA}$, Weiss $\mathrm{RH}$. New opportunities from the cancer metabolome. 
Clin Chem. 2013;59:138-46.

14. Jacob M, Lopata AL. Dasouki M, Abdel Rahman AM. Metabolomics toward personalized medicine. Mass Spectrom Rev. 2017 (in press). doi:10.1002/mas.21548.

15. Patel S, Ahmed S. Emerging field of metabolomics: Big promise for cancer biomarker identification and drug discovery. J Pharm Biomed Anal. 2015; 107:63-74

16. Gao L, Wen Z, Wu C, Wen T, Ong CN. Metabolic profiling of plasma from benign and malignant pulmonary nodules patients using mass spectrometry-based metabolomics. Metabolites. 2013;3:539-551.

17. Shen J, Yan L, Liu S, Ambrosone CB, Zhao H. Plasma metabolomic profiles in breast cancer patients and healthy controls: by race and tumor receptor subtypes. Transl Oncol. 2013;6:757-65.

18. Pérez-Rambla C, Puchades-Carrasco L, García-Flores M, Rubio-Briones J, López-Guerrero JA, Pineda-Lucena A. Non-invasive urinary metabolomic profiling discriminates prostate cancer from benign prostatic hyperplasia. Metabolomics. 2017;13:52

19. Pasikanti KK, Esuvaranathan K, Hong Y, Ho PC, Mahendran R, Raman Nee Mani L, et al. Urinary metabotyping of bladder cancer using two-dimensional gas chromatography time-of-flight mass spectrometry. J Proteome Res. 2013;12:3865-73.

20. Tripathi P, Somashekar BS, Ponnusamy M, Gursky A, Dailey S, Kunju P, et al. HR-MAS NMR tissue metabolomic signatures cross-validated by mass spectrometry distinguish bladder cancer from benign disease. J Proteome Res. 2013;12:3519-28.

21. Snyder NW, Mesaros C, Blair IA. Translational metabolomics in cancer research. Biomark Med. 2015:9:821-34.

22. Cheng $Y$, Yang $X$, Deng $X$, Zhang X, Li P, Tao J, et al. Metabolomics in bladder cancer: a systematic review. Int J Clin Exp Med. 2015;8:11052-63.

23. Armitage $\mathrm{EG}$, Barbas $\mathrm{C}$. Metabolomics in cancer biomarker discovery: Current trends and future perspectives. J Pharm Biomed Anal. 2014;87:111.

24. Barding GA, Salditos R, Larive CK. Quantitative NMR for bioanalysis and metabolomics. Anal Bioanal Chem. 2012;404:1165-79.

25. Gika HG, Theodoridis GA, Plumb RS, Wilson ID. Current practice of liquid chromatography-mass spectrometry in metabolomics and metabonomics. J Pharm Biomed Anal. 2014;87:12-25.

26. Halket JM, Waterman D, Przyborowska AM, Patel RKP, Fraser PD, Bramley PM. Chemical derivatization and mass spectral libraries in metabolic profiling by GC/MS and LC/MS/MS. J Exp Botany. 2005;56:219-43.

27. Issaq HJ, Nativ O, Waybright T, Luke B, Veenstra TD, Issaq EJ, et al. Detection of bladder cancer in human urine by metabolomic profiling using high performance liquid chromatography/mass spectrometry. J Urol. 2008:179:2422-6.

28. Srivastava S, Roy R, Singh S, Kumar P, Dalela D, Sankhwar SN, et al. Taurine - a possible fingerprint biomarker in non-muscle invasive bladder cancer: A pilot study by $1 \mathrm{H}$ NMR spectroscopy. Cancer Biomark. 2010;6:11-20.

29. Jin X, Yun SJ, Jeong P, Kim IY, Kim WJ, Park S. Diagnosis of bladder cancer and prediction of survival by urinary metabolomics. Oncotarget. 2014; 5: 1635-45

30. Shen C, Sun Z, Chen D, Su X, Jiang J, Li G, et al. Developing urinary metabolomic signatures as early bladder cancer diagnostic markers. Omi A J Integr Biol. 2015;19:1-11.

31. Dettmer K, Vogl FC, Ritter AP, Zhu W, Nürnberger N, Kreutz M, et al. Distinct metabolic differences between various human cancer and primary cells. Electrophoresis. 2013:34:2836-47.

32. Conde VR, Oliveira PF, Nunes AR, Rocha CS, Ramalhosa E, Pereira JA, et al. The progression from a lower to a higher invasive stage of bladder cancer is associated with severe alterations in glucose and pyruvate metabolism. Exp Cell Res. 2015;335:91-8.

33. Wittmann BM, Stirdivant SM, Mitchell MW, Wulff JE, McDunn JE, Li Z, et al. Bladder cancer biomarker discovery using global metabolomic profiling of urine. PLoS One. 2014;9: e115870.

34. Alberice JV, Amaral AFS, Armitage EG, Lorente JA, Algaba F, Carrilho $E$, et al. Searching for urine biomarkers of bladder cancer recurrence using a liquid chromatography-mass spectrometry and capillary electrophoresis-mass spectrometry metabolomics approach. J Chromatogr A. 2013;1318:163-70

35. Sahu D, Lotan Y, Wittmann B, Neri B, Hansel DE. Metabolomics analysis reveals distinct profiles of nonmuscle-invasive and muscle-invasive bladder cancer. Cancer Med. 2017; 6:2106-20

36. Bansal N, Gupta A, Mitash N, Shakya PS, Mandhani A, Mahdi AA, et al. Low- and high-grade bladder cancer determination via human serum-based metabolomics approach. J Proteome Res. 2013;12:5839-50.

37. Rodrigues D, Jerónimo C, Henrique R, Belo L, de Lourdes Bastos M, de Pinho PG, et al. Biomarkers in bladder cancer: A metabolomic approach using in vitro and ex vivo model systems. Int J Cancer. 2016;139:256-68.

38. Kim JW, Lee G, Moon SM. Metabolomic screening and star pattern recog- nition by urinary amino acid profile analysis from bladder cancer patients Metabolomics. 2010;6:202-6.

39. Pasikanti KK, Esuvaranathan K, Ho PC, Mahendran R, Kamaraj R, Wu $\mathrm{QH}$, et al. Noninvasive urinary metabonomic diagnosis of human bladder cancer. J Proteome Res. 2010;9:2988-95.

40. Huang Z, Lin L, Gao Y, Chen Y, Yan X, Xing J, et al. Bladder cancer determination via two urinary metabolites: a biomarker pattern approach. Mol Cell Proteomics. 2011:10:M111.007922.

41. Ghafouri-Fard S, Nekoohesh L, Motevaseli E. Bladder cancer biomarkers: review and update. Asian Pac J Cancer Prev. 2014;15:2395-403.

42. Fujimura $\mathrm{Y}$, Ikenaga N, Ohuchida K, Setoyama D, Irie M, Miura D, et al. Mass spectrometry-based metabolic profiling of gemcitabine-sensitive and gemcitabine-resistant pancreatic cancer cells. Pancreas. 2014;43:311-8.

43. Wang X, Yan SK, Dai WX, Liu XR, Zhang WD, Wang JJ. A metabonomic approach to chemosensitivity prediction of cisplatin plus 5-fluorouracil in a human xenograft model of gastric cancer. Int J Cancer. 2010;127:284150. 